\title{
In-vitro studies of the effects of interferons on endometrial metabolism in sheep
}

\author{
L. A. Salamonsen, R. A. Cherny and J. K. Findlay \\ Prince Henry's Institute of Medical Research, P,O. Box 118. South Melbourne, Victoria 3205, \\ Australia
}

\begin{abstract}
Summary. Primary cultures of ovine epithelial and stromal cells have been used to examine paracrine interactions between the endometrium and the preimplantation sheep blastocyst, and in particular the actions of the blastocyst $\alpha$-interferon, ovine trophoblast protein-1 (oTP-1), on endometrial cell metabolism. The synthesis and secretion of seyeral 'pregnancy-related' acidic proteins with molecular weights in the range $70000-120000$ can be induced by addition of oTP-1 or human recombinant interferon (IFN) to cultured enriched epithelial endometrial cells. Consistent with the antiluteolytic role of oTP-1, dose-dependent attenuation of both PGE and PGF- $2 \alpha$ release has been demonstrated. Arachidonic acid added to the cells increased overall PG release but the inhibitory effects of interferons were still apparent. Immunocytochemical analysis of PG synthase demonstrated marked cyclic variation of its localization within the endometrium, but no differences in distribution or intensity of staining were apparent in endometrium of early pregnancy (Day 15) compared with that of the cycle (Day 15). It appears that conceptus-induced changes in PG release do not occur via changes in concentration or localization of PG synthase but rather by modifying its activity. Highly purified epithelial cells cultured on matrigel-coated millicell inserts retain important morphological features seen in vivo. Under such conditions, PGF-2 $\alpha$ and PGE release into the basal compartment was greater than that into the apical compartment. Stromal fibroblasts cultured under similar conditions secreted less PGF$2 \alpha$ but more PGE than epithelial cells. Whilst the limitations of in-vitro studies are acknowledged, these findings are compatible with and markedly extend what is known of the action of embryonic interferons in vivo in the establishment of pregnancy in sheep.
\end{abstract}

Keywords: sheep; endometrium; trophoblast interferon; cell culture; prostaglandins; protein secretion

\section{Introduction}

The uterus, more than any other organ, is responsive to the continually changing endocrine status of its environment during the oestrous cycle and to paracrine regulation by embryonic factors in early pregnancy (Findlay et al., 1990a; Salamonsen \& Findlay, 1990a). In-vivo studies of endometrial metabolism can therefore be difficult to interpret because of the myriad of regulatory factors acting in concert. This is particularly the case in ruminant species on account of the interrelationship between the endometrium and the preimplantation blastocyst with its marked elongation and increased secretory capacity.

The use of in-vitro systems allows study of physiological mechanisms under more carefully controlled conditions than is possible in vivo. Various in-vitro models have been used in the study of endometrial physiology, and these have generally utilized tissue explants in simple culture flasks or in perifusion chambers, or cultures of isolated cells of either mixed or single cell types (Findlay et 
al., 1990b). Each model has its advantages and disadvantages but each can make its contribution. In our laboratory, the decision to develop systems for the culture of separated epithelial and stromal cells from the sheep endometrium was made for a number of reasons. Firstly, isolated cells are free from effects mediated either by another cell type or via blood flow. Blood flow effects are of particular importance in the endometrium in which hyperaemia and vascular permeability vary depending on the hormonal and pregnancy status of the subject. Secondly, the responsiveness of a cell to a given stimulus can be studied for prolonged periods in culture, this not being possible with explants or in in-vive studies. Thirdly, the number of cells in an experimental sample can be varied according to the requirements for subsequent analysis and good reproducibility can be obtained between replicates. Finally, and most importantly, the use of highly purified cell types allows identification of para- and autocrine factors involved in control of endometrial function. Against such advantages must be weighed a number of disadvantages. The study of one population of cells fails to define the activity of the organ as a whole and there may be a lack of, or change in, responsiveness of the cells in culture and their functional character compared with those in whole tissue. In addition selection of a particular subpopulation of a cell-type may occur, the action of digestive enzymes may alter cell surface receptors or the cells may change in culture, becoming dedifferentiated. Such factors must be considered in the interpretation of results.

In the ewe, the major protein secreted by the preimplantation blastocyst, ovine trophoblast protein 1 (oTP-1, Godkin et al., 1982), is present in exceptionally high concentrations in the uterine lumen from Day 12 or 13 of pregnancy until well after implantation (Day 16; Hansen et al., 1988), but it appears not to enter the maternal circulation (see Bazer et al., 1986). Consequently, its actions are most likely to be restricted to paracrine regulation of endometrial function. oTP-1 is an $\alpha$-interferon (Imakawa et al., 1987; Stewart et al., 1987; Charpigny et al., 1988) and appears to be the major blastocyst-derived factor responsible for maintenance of the corpus luteum in early pregnancy (Bazer et al., 1987). Whilst in-vivo studies have demonstrated the antiluteolytic activity of this protein (Vallet et al., 1988), in-vitro models are more appropriate for detailed studies of its mechanism of action. We have used cell culture systems to examine the paracrine effects of oTP-1 and alpha-interferon on endometrial cell function.

\section{Isolation and culture of ovine endometrial cells}

\section{Isolation and enrichment of cells}

Uteri are removed from ewes (either from intact animals on a specified day of the oestrous cycle, or from ovariectomized ewes treated with Silastic implants of oestrogen and/or progesterone and endometrial tissue is dissected cleanly from the myometrium. The original method used to separate stromal from epithelial cells involved collagenase treatment of chopped tissue and enrichment of epithelial cells on a Ficoll gradient (Salamonsen et al., 1985). Such preparations have yielded much valuable data but suffer several disadvantages. Contamination of epithelial with stromal cells (up to $20 \%$ ) is unacceptable for studies of stromal-epithelial cell interactions. The nature of the proteins secreted by the epithelial cells alters by 7 days of culture, suggesting differentiation of the cells with time, and stromal cells prepared by this method do not attach and grow on plastic in primary culture. Recent modification of the original method omits the Ficoll gradient step and uses selective trypsinization and replating, resulting in cultures of highly purified epithelial and stromal cells which appear stable for longer periods of time than those prepared by the original method (Cherny \& Findlay, 1990).

\section{Identification of cultured cells}

A major requirement of studies using separated cells is proper identification of the cell types. Ideally, a combination of several methods should be used. Those most readily available are phase-contrast and electron microscopy and specific immunohistochemical staining. 
Under transmission electron microscopy, luminal epithelial cells of both the caruncular and intercaruncular regions in situ are simple columnar cells with junctional complexes containing desmosomes in the lateral walls (Salamonsen et al., 1985). Glandular epithelial cells are similar but can be ciliated. All the epithelial cells are characterized by having microvilli and prominent nucleoli and are sometimes surrounded by a glycocalyx. Often, abundant glycogen and polyribosomes can be seen, together with bundles of microfilaments in the marginal cytoplasm. Isolated epithelial cells retain these in-situ morphological characteristics and differ markedly from stromal fibroblasts, which have irregular nuclei, no surface microvilli and no desmosomes at mesenchymal cell junctions. In addition, stromal cells have a higher nuclear to cytoplasmic ratio than do epithelial cells and are not polarized in situ. The epithelial cells are polarized in situ but polarity appears to be lost when they attach to plastic.

The intermediate filament proteins are characteristic of individual cell types and the fact that cytokeratin is ubiquitous in epithelial cells has been used to identify ovine endometrial epithelial cells by immunocytochemical means (Salamonsen et al., 1985). For the stromal cells, fibronectin, a component of the extracellular matrix secreted by fibroblasts is used as a positive marker (Cherny \& Findlay, 1990). The absence of endothelial cells has been established by lack of staining with antiserum to Factor VIII.

\section{Culture of isolated cells}

In our original method, epithelial cells were initially plated in Medium 199 containing heat-and charcoal-treated fetal calf serum which facilitates attachment and spreading. After overnight incubation, the medium could be changed to serum-free if desired and the cells maintained in this for several days without apparent change of function. For examination of protein synthesis and secretion by the cells, a $24-\mathrm{h}$ incubation in methionine-free medium containing added $\left[{ }^{35} \mathrm{~S}\right]$ methionine was carried out without loss of viable cells.

In the modified method (Cherny \& Findlay, I990), separated stromal or epithelial cells are plated on to Millicell culture well inserts (Millipore, Bedford, MA, USA). The nitrocellulose membrane which forms the attachment surface is precoated with rat sarcoma extracellular matrix (Matrigel; Collaborative Research, Bedford, MA, USA). When grown on Matrigel-coated inserts, epithelial cells retain their characteristic polarized morphology for $>2$ weeks, with tight junctions between the cells and cilia visible on the apical surfaces (Fig 1a). Epithelial colonies maintained on plastic in the absence of stromal cells quickly flatten and lose their characteristic cobblestone appearance, cell size increases dramatically, vacuoles appear in the cytoplasm and cell borders contract. Highly-purified stromal preparations grown on plastic commonly, though not invariably, aggregate in large detached clumps after several days in culture and this is prevented by culture on Matrigel-coated inserts (Fig. 1b). The insert culture method is most suited to studies of cellular source of substances and directionality of epithelial cell secretion and for examination of paracrine interactions both between epithelial and stromal cells and between epithelium and trophoblast.

\section{Effects of interferons on metabolism of endometrial cells}

\section{Protein synthesis and secretion}

Early studies using endometrial explants (Findlay et al., 1981, 1982) demonstrated a quantitative increase in the rate of $\left[{ }^{3} \mathrm{H}\right]$ leucine incorporation into cellular protein by endometrium of pregnant ewes before implantation but secreted proteins were not examined. Furthermore Godkin et al. (1984) demonstrated that oTP-I bound specifically to ovine endometrium and increased the rate of protein release by endometrial explants of non-pregnant ewes. We subsequently showed significantly higher incorporation of $\left[{ }^{35} \mathrm{~S}\right]$ methionine into secreted protein by cultured epithelial cells derived from pregnant (Day 13) compared with non-pregnant ewes (Salamonsen et al, 1986). 
(a)
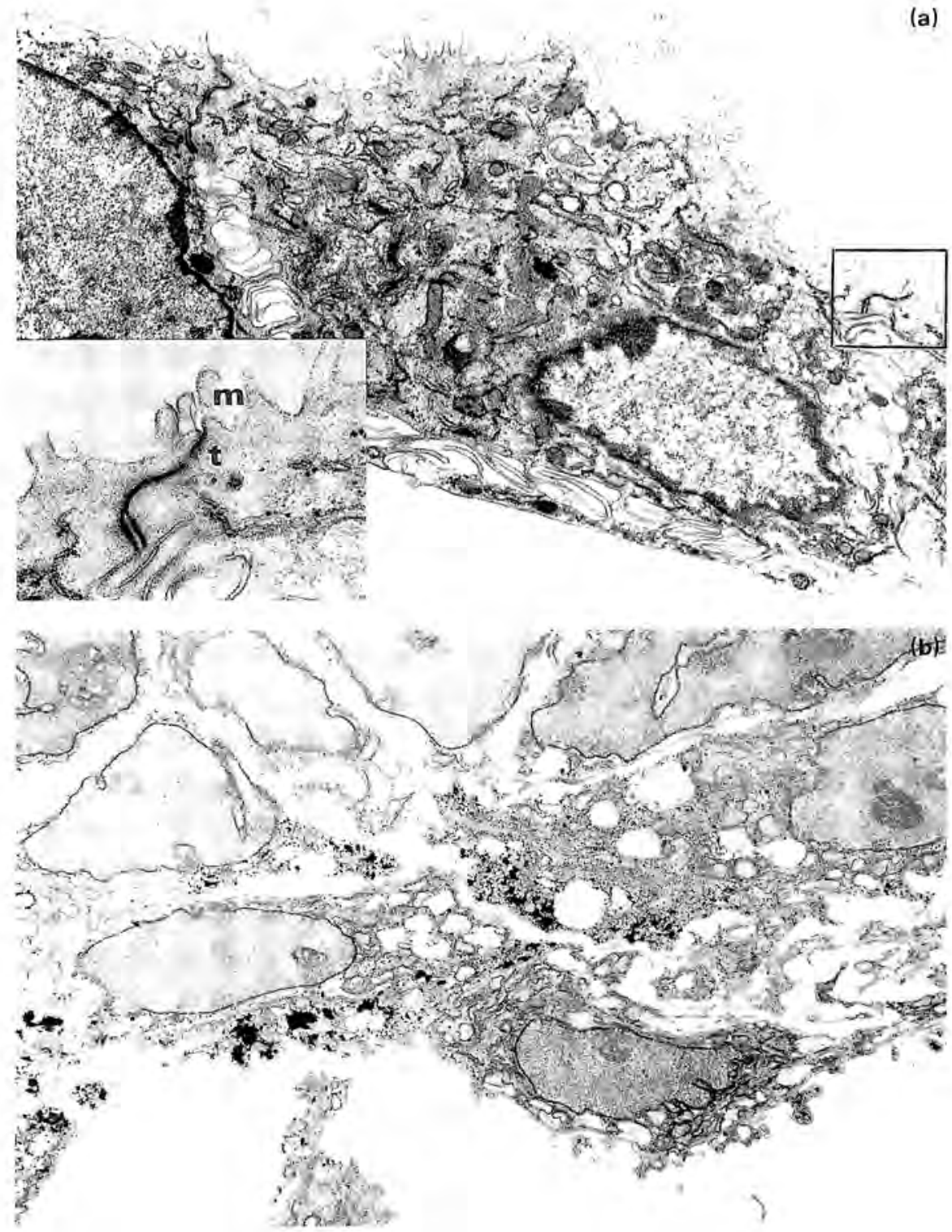

Fig. 1. Transmission electron micrographs of: (a) confluent epithelial cell culture with cross section showing prominent microvilli $(\mathrm{m})$ and tight junctions $(\mathrm{t})$ and $(\mathrm{b})$ confluent stromal cultures, both on Matrigel-coated Millicell inserts. $\times 3000$. (From Cherny \& Findlay 1990.)

Secretion by cells from non-pregnant ewes was increased by addition of media conditioned by Day15 blastocysts. Analysis by two-dimensional polyacrylamide gel electrophoresis showed 5 secreted proteins (mol. wt range 74 000-120 000; isolectric point $<6.5$ ) which were either absent or present in only small amounts in secretions from cells from non-pregnant ewes but were greatly enhanced in secretions from cells from pregnant ewes. The addition of blastocyst-conditioned medium to cultures from non-pregnant ewes enhanced the secretion of these same proteins which were similar in molecular weight and acidic nature to those observed by Godkin et al. (1984) to be stimulated when purified oTP-1 was added in vitro to endometrial explants from Day 12 non-pregnant ewes. 
We have subsequently examined the effects of pure oTP-1 and of the homologue human interferon $\alpha 2 \mathrm{a}$ (IFN; Roferon-A, Hoffman La Roche, Basel, Switzerland) on proteins secreted by primary cultures of enriched epithelial cells derived from oestradiol plus progesterone-treated ovariectomized ewes and shown that both interferons stimulated synthesis and secretion of the same 'pregnancy-related' proteins seen in the previous study with the exception of one protein which was seen only in the presence of oTP-L/IFN in the latter experiment (Salamonsen et al., 1988). Quantitation of the effects of oTP- 1 on secreted proteins using $\left[{ }^{3} \mathrm{H}\right]$ - and $\left[{ }^{35}\right.$ S $]$ methionine and endometrial explants from Day 12 non-pregnant ewes (Vallet et al., 1987) showed amplification of the secretion of at least 11 proteins and reduction of at least 6 by oTP- 1 in vitro. Synthesis of the two major oTP-1-dependent proteins has subsequently been shown to coincide with the time oTP-1 is maximally released by the blastocyst (Sharif et al., 1989). The pl and molecular weight range of these proteins correlated well with those of our study and that of Godkin et al. (1984), the numerical difference probably relating to the use of tissue explants compared with enriched epithelial cells. The structure and function of these 'pregnancy-related' proteins remain to be determined. The electrophoretic profiles of proteins secreted by highly purified epithelial and stromal cells cultured on Millicell inserts differ markedly from one another (Cherny \& Findlay, 1988), and it is clear that in studies using mixed cell populations the relative numbers of the major cell types can influence the relative intensities of individual proteins. Indeed, stromal cells release significantly more newly synthesized protein than do epithelial cells (Fig. 2a). In addition epithelial cells cultured on inserts release more protein apically than basally (Fig. 2b). It will clearly be of interest to determine which of the proteins whose synthesis and secretion is modified by OTP-1 are secreted apically (into the uterine lumen in vivo) and which are secreted basally (towards the stroma and vasculature).
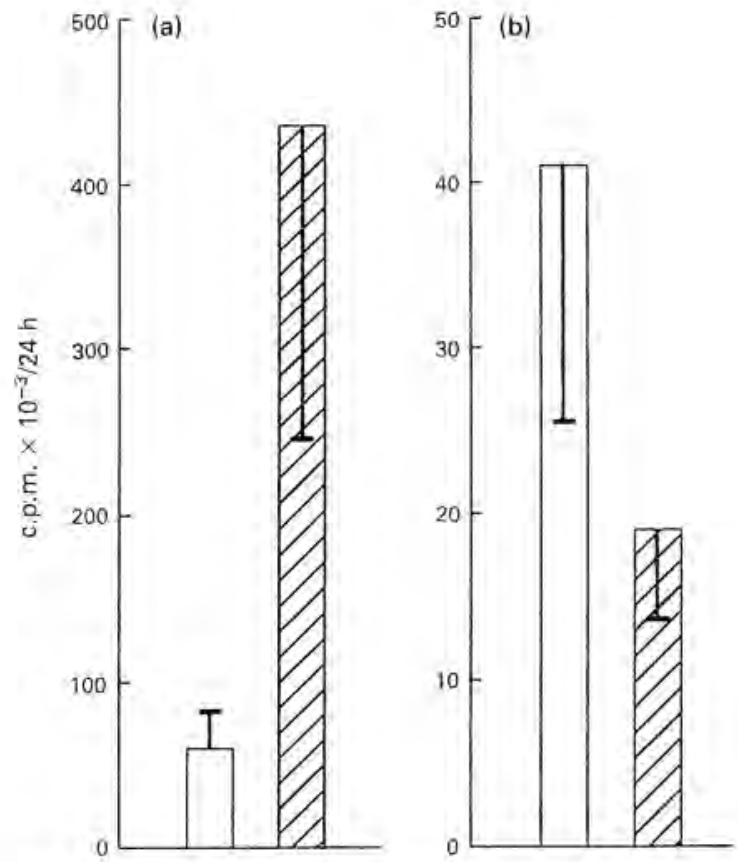

Fig. 2. Release of newly synthesized protein containing incorporated $\left[{ }^{35}\right.$ S $]$ methionine (a) from epithelial $(\square)$ and stromal $(\mathbb{Z})$ cells grown on inserts (no Matrigel); and (b) released into apical $(\square)$ and basal (®) compartments by epithelial cells on inserts. Values are mean \pm s.e.m., $N=$ 4 ewes. 


\section{Prostaglandin synthesis and secretion}

Cellular origin and vectorial secretion of prostaglandins. Culture of highly purified epithelial and stromal cells on Matrigel-coated Millicell inserts have demonstrated marked differences in PG release by the two cell types (Cherny \& Findlay, 1990). Whilst PGE is secreted primarily by stromal cells, the epithelial cells are the major source of PGF-2 $\alpha$ (Fig. 3), a pattern also established by Fortier et al. (1988) for bovine endometrial cells. Moreover, epithelial cells grown to confluence on inserts and in which the presence of tight junctions could be demonstrated, displayed polarized release of both PGE and PGF-2 $\alpha$, with mean basal secretion being $3 \cdot 3$ (s.e. $\pm 0 \cdot 8, n=3$ ) and $4 \cdot 4$ (s.e. $\pm 1 \cdot 0, n=8$ ) times that of apical secretion respectively over a 24 -h culture period (Fig. 4). These data are in agreement with the proposal of Bazer \& Thatcher (1977) that most of the PGF release from the ovine endometrium must be in a myometrial direction, but contrast with results from perifusion experiments which show PGF-2 $\alpha$ secretion to favour the luminal direction in sheep (Lacroix \& Kann, 1983; Vallet et al., 1989) and cattle (Gross et al., 1988a). Such contrasting results may be a function of the different in-vitro techniques used or may be indicative of disruption of control mechanisms which require the co-operation of closely-apposed epithelium and stroma. It must also be remembered that our study was restricted to the two major cell types and the possibility exists that other cell types within the stroma (e.g. lymphoctyes) may contribute to the total PG output of the endometrium or that luminal and glandular epithelium exhibit different patterns of secretion.
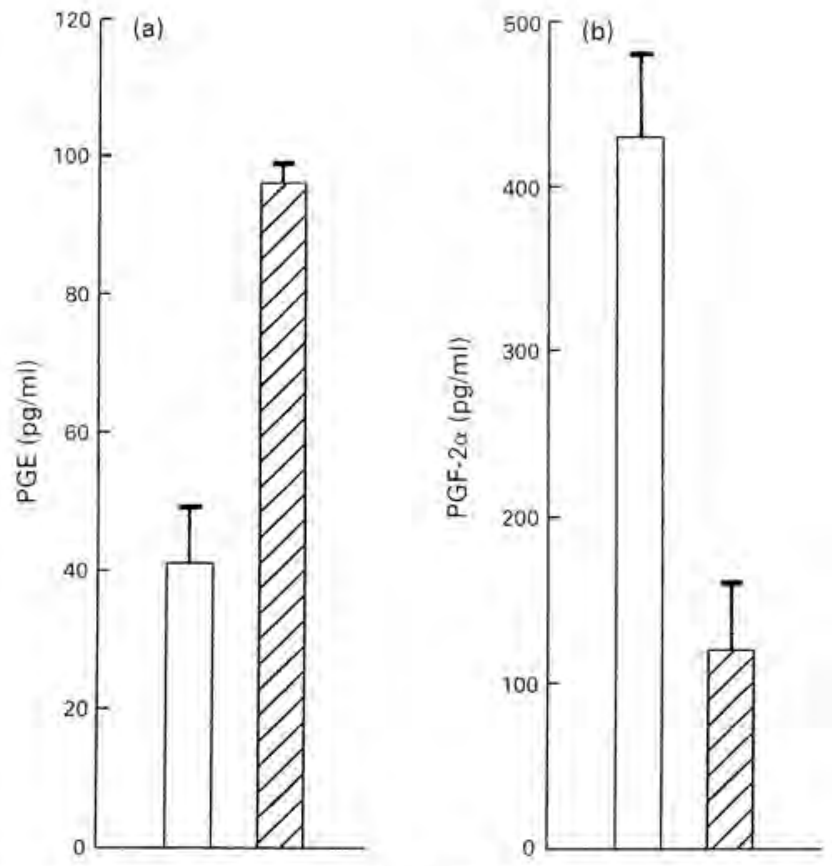

Fig. 3. PGE (a) and PGF-2 $\alpha$ (b) secretion by epithelial ( $\square$ ) and stromal ( 2 ) cells grown on inserts (no Matrigel). Values are mean \pm s,e.m., for $\mathrm{N}=3$ and 8 ewes respectively. (After Cherny \& Findlay, 1990.)

Effects of oTP-1. Evidence from in-vivo studies suggests that oTP-1 has an important role in preventing PG release and hence luteolysis in early pregnancy. Infusion of oTP-1 into the uterine lumen of cycling ewes prolonged the oestrous cycle up to a mean of 27 days and maintained the production of progesterone by the corpus luteum (Godkin et al., 1984; Vallet et al., 1988). We have demonstrated a direct inhibitory effect of oTP-1 on release of both PGF-2 $\alpha$ and PGE from ovine 

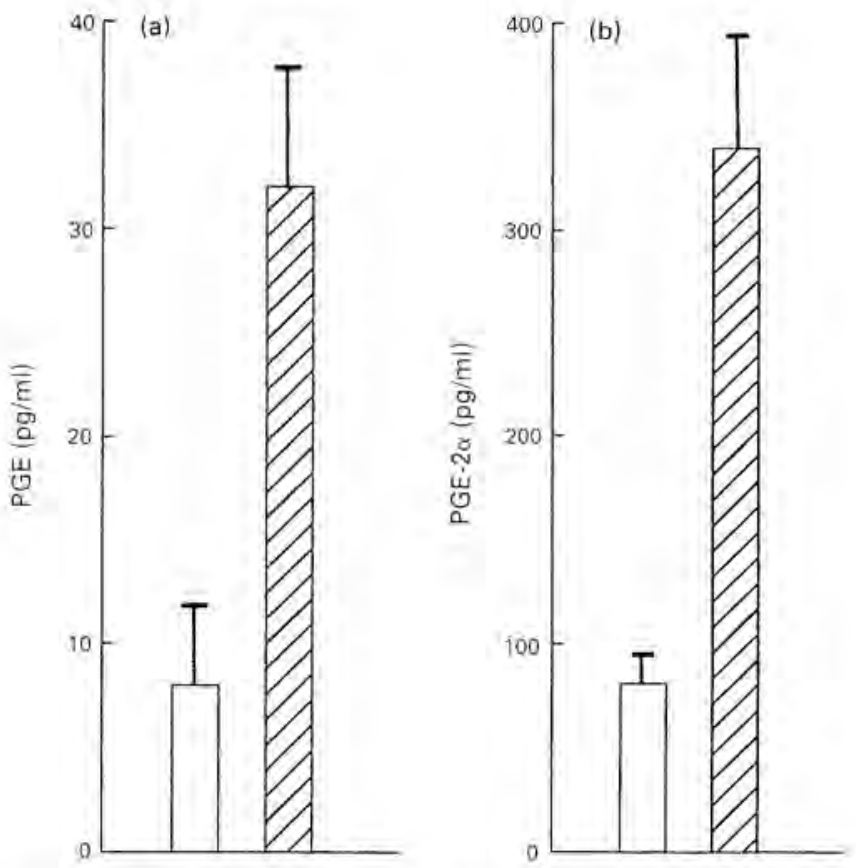

Fig. 4. Release of PGE (a) and PGF-2 $\alpha$ (b) into the apical ( $\square$ ) and basal ( from epithelial cells grown on inserts (no Matrigel). Values are mean \pm s.e.m., for $\mathrm{N}=3$ and 8 ewes respectively. (After Cherny \& Findlay, 1990.)

endometrial cells in primary culture, an action mimicked by IFN (Salamonsen et al., 1988). These inhibitory actions of oTP-I and IFN were dose-dependent and parallel, with both IFNs being highly potent $\left(\mathrm{IC}_{50}\right.$ of $10^{-11} \mathrm{M}$ for oTP-1 and $10^{-13} \mathrm{M}$ for IFN; Salamonsen el al., I989), the differences reflecting the known differences in antiviral activity of human IFNs on bovine compared with human cells (Weck et al., 1981). Why such large amounts of oTP-1 (up to $100 \mu \mathrm{g}$ in $30 \mathrm{~h}$ of culture; Ashworth \& Bazer, 1989) are released by the preimplantation blastocyst when it is of such high potency remains an enigma. It may be that much of it is inactivated or sequestered within the uterine lumen or that the high concentrations are required for some alternative action.

What is the mechanism of the inhibitory action of oTP-1 on endometrial PG release? Timecourse studies using cell cultures showed no measurable effect before $12 \mathrm{~h}$ after addition of oTP-1 to the culture dishes. Following removal of the interferons, the cells released less PGs for a further $18 \mathrm{~h}$ but then recovered (Salamonsen et al., 1989). Addition of arachidonic acid to the cell cultures increased the overall release of both PGE and PGF-2 $\alpha$ but did not affect the inhibitory action of oTP-1 on release of either PG (Fig. 5). IFN affected neither the uptake of $\left[{ }^{3} \mathrm{H}\right]$ arachidonic acid by endometrial cells, nor the incorporation of the arachidonic acid into cellular lipid (Salamonsen $e t$ al., 1989). It is therefore likely that OTP-I is acting either directly or indirectly on the prostaglandin synthase enzyme, although an additional effect on other enzymes such as phospholipase $\mathrm{A}_{2}$ cannot be discounted. In the cow, there is considerable evidence that bovine trophoblast protein-1 (which is also an $\alpha$-interferon) induces an intracellular inhibitor of PG synthesis (Basu \& Kindahl, 1987; Gross et al., 1988b; Helmer et al., 1989) and there is preliminary evidence for a similar inhibitor in the sheep (Basu \& Kindahl, 1989).

Immunocytochemical localization of PG synthase during the oestrous cycle and early pregnancy (Salamonsen \& Findlay, 1990b) has contributed further clues to the mechanism of action of the interferons on PG release. Throughout the oestrous cycle marked changes in location of the 

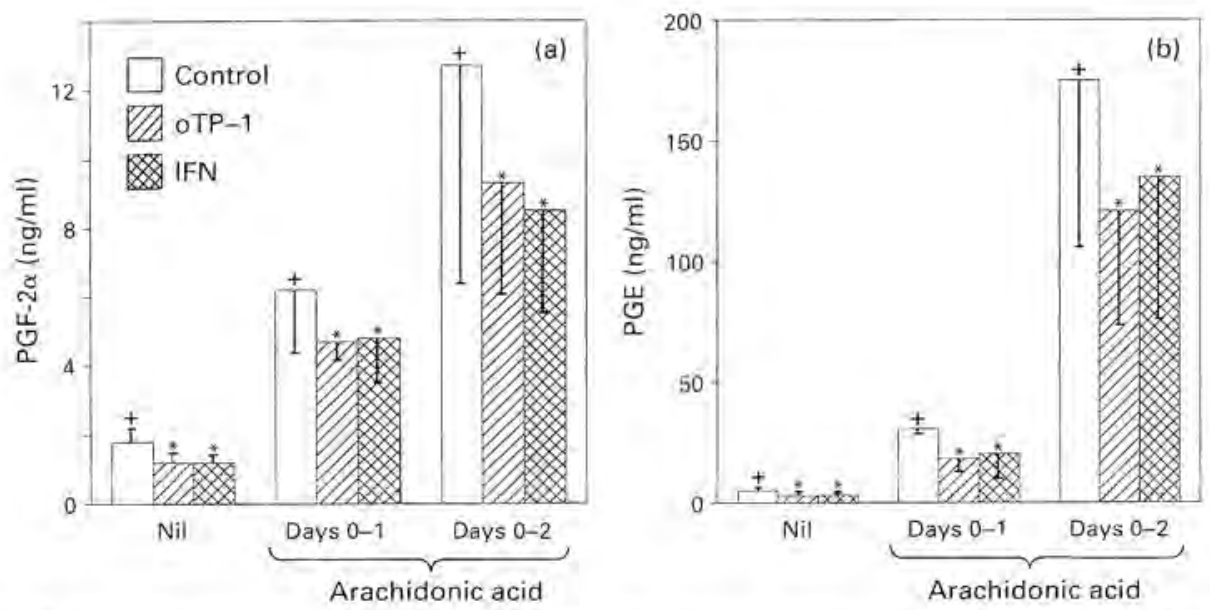

Fig. 5. Effect of exogenous arachidonic acid on the attenuation by oTP-1 and IFN of PGE and PGF-2 $\alpha$ release from endometrial cells in culture. Within each group different symbols $(+, *)$ represent significant differences, $P<0 \cdot 01$. (From Salamonsen \& Findlay, 1990a.)

enzyme occur. On Day 4, PG synthase is located primarily in the stromal cells in caruncular and intercaruncular tissue with little staining in the epithelium (Fig. 6a), whilst on Days 14-16, the most intense staining is in the luminal epithelial cells (both caruncular and intercaruncular) and in epithelial cells of glands close to the uterine lumen (Fig. 6b). Some staining is also seen in the stromal cells, particularly close to the myometrium. On Day 15 of pregnancy, the pattern of staining is identical to that on Day 15 of the cycle with no detectable difference in intensity. When endometrial cells (cycle, Day 14) were cultured with and without oTP-1 $(3 \mathrm{ng} / \mathrm{ml})$ in vitro, release of PGE and PGF- $2 \alpha$ was attenuated ( $54 \%$ and $47 \%$ of control respectively) but no differences were observed in the intensity of staining for PG synthase in the cells. However, in an earlier study (Cerini et al., 1979), immunolocalization of PGF, the product of PG synthase action, was different in pregnant compared with non-pregnant tissue. Whilst the PGF was detected on the surface and in the cytoplasm of luminal epithelial cells with small amounts in the stroma in the cyclic ewe after Day 11, in pregnant ewes (Day 3-17) it was localized primarily in the stroma. Therefore in early pregnancy, in spite of the presence of PG synthase, there is little or no PGF produced by the epithelial cells. It would therefore appear that conceptus-induced changes in PG release do not occur via changes in the concentration or cellular localization of PG synthase, but rather that the activity of the enzyme is modified or its substrate and/or cofactors are limiting. In vivo it is the pulses of PGF- $2 \alpha$ that are absent in the pregnant ewe whilst basal PG production is not altered (see McCracken et al., 1984). Moreover, pregnant ewes have higher basal concentrations of 15-keto-13,14-dihydro-PGF-2 $\alpha$ (PGFM) than do cyclic ewes on Day 15 (Peterson et al., 1976; Fincher et al., 1986) and, in vitro, more PGF is produced from endometrium of pregnant than non-pregnant ewes (Lacroix \& Kann, 1983) and pregnancy stimulates basal but not oxytocin-induced secretion of endometrial PGF (Vallet et al., 1989). We would therefore postulate that most basal PG production may occur in the stroma, controlled by one set of regulatory mechanisms (possibly ovarian steroids) whilst the overlying pulsatile PG may arise from the epithelium with a different set of regulators (Fig. 7). Both oTP-I and oxytocin have demonstrated roles in regulation of endometrial PGs (McCracken et al., 1984; Flint et al., 1986; Salamonsen et al., 1989), the two regulators acting through different second messenger systems (Flint et al., 1986; Vallet et al., 1987, 1989). However oTP-1 does not compete with oxytocin for its receptor (Bazer et al., 1987) Receptors for both oTP-1 and oxytocin (Godkin et al., 1984; L. A. Salamonsen \& J. K. Findlay, unpublished observations; Philpott et al., 1985) are present on ovine endometrial epithelial cells. Thus oTP-1 and ovarian oxytocin are possible contenders for the role of regulators of epithelial cell PG synthase activity. 

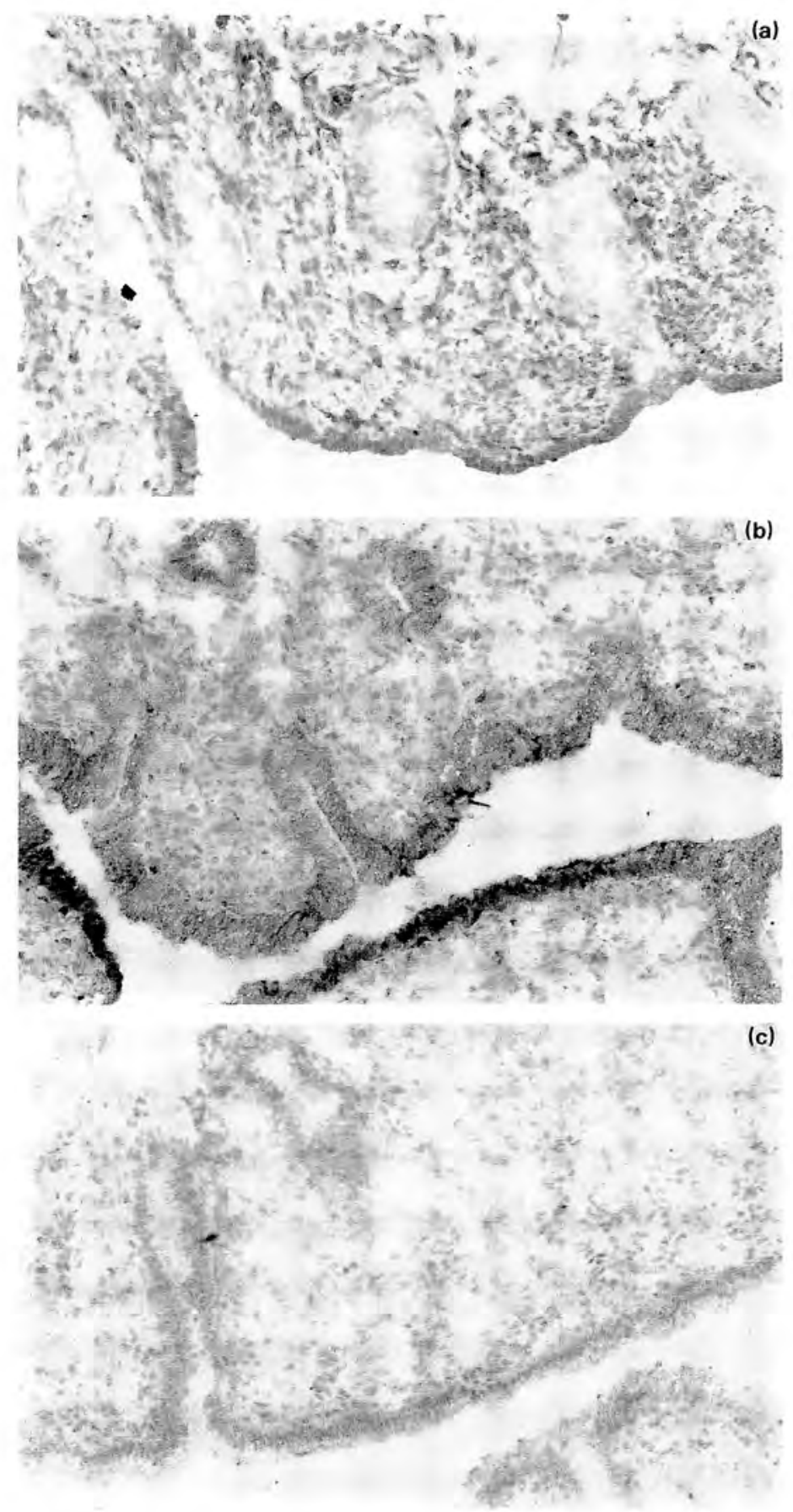

Fig. 6. Immunocytochemical localization of PG synthase in ovine endometrium derived from Day 4 (a) and Day 15 (b) cycling ewes. Control (c) had no primary antiserum. Original magnification, $\times$ 100. (After Salamonsen \& Findlay, 1990b). 


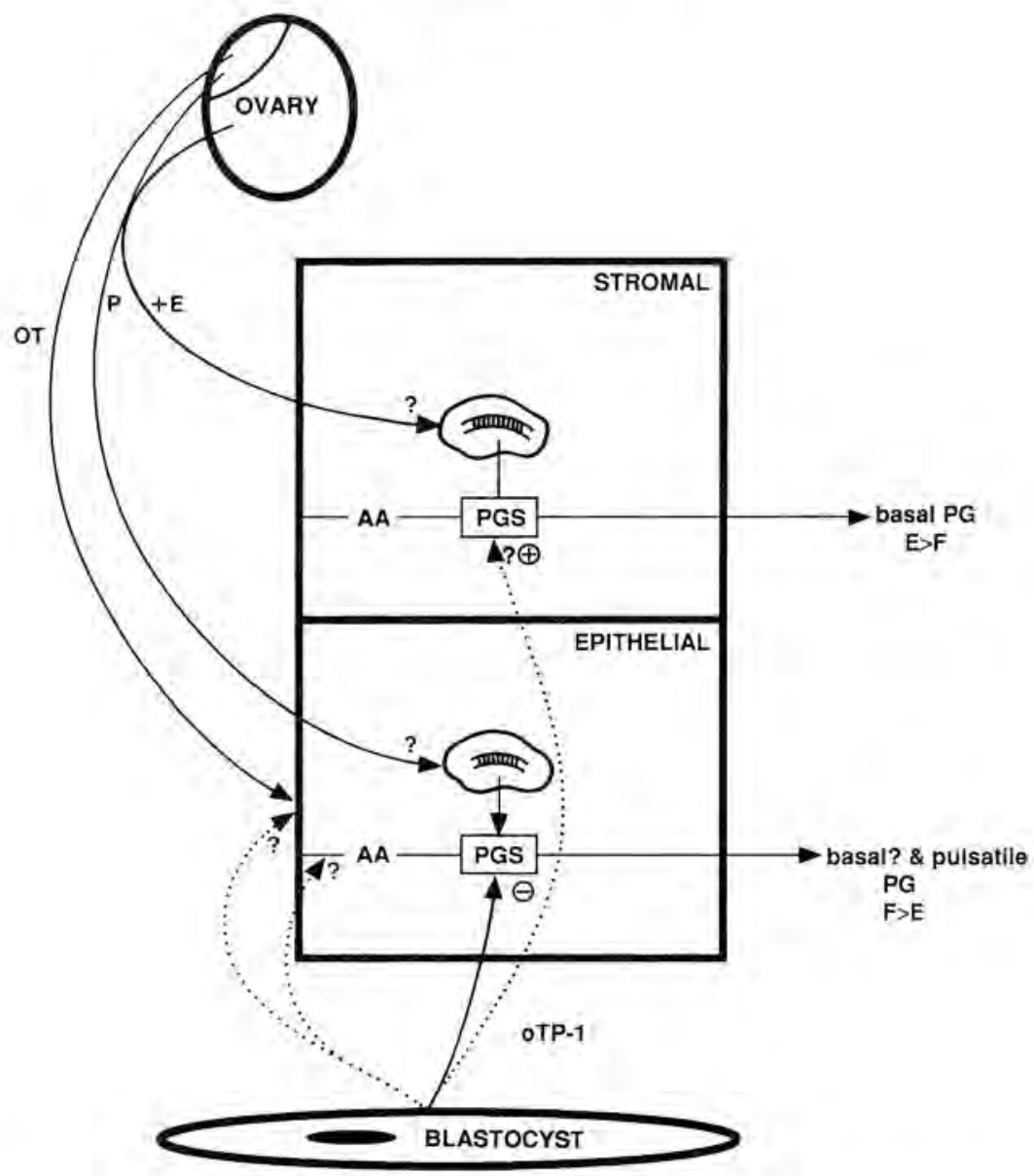

Fig. 7. Postulated mechanisms for regulation of PG release from ovine endometrial stromal and epithelial cells in early pregnancy. PGS $=$ prostaglandin synthase; $\mathrm{AA}=$ arachidonic acid; $\mathrm{OT}=$ oxytocin $; \mathrm{P}=$ progesterone $; \mathrm{E}=$ oestradiol.

\section{Conclusions}

Whilst in-vitro systems have contributed to our knowledge of the endometrial responses to the paracrine effects of embryonic IFNs in ruminant species there remain many unanswered questions. The mechanism of action of the IFNs on prostaglandin release and on protein secretion and the nature and function of the IFN-induced proteins is as yet unknown, as is the means by which IFN receptors are regulated. There are likely to be other physiologically important effects of IFNs including immunomodulation and regulation of cell proliferation. Although oTP-1 related molecules have been identified in most ruminant species, whether or not their actions are similar remains to be determined. It is likely that IFNs are not the only embryonic factors of importance in early pregnancy (Salamonsen \& Findlay, 1990a), nor indeed the only blastocyst-derived antiluteolytic factors in ruminants (Stewart et al., 1989). Interactions between other putative factors and the IFNs are likely to occur. The limitations of in-vivo models for examining such complex systems are obvious. It is only by examining the interactions between individual cellular components of the embryo-maternal functional unit (embryo-trophoblast-endometrial epithelium-endometrial 
stroma-endothelium) in in-vitro systems such as those described in this review that we will come to a fuller understanding of the mechanisms by which this unit functions.

The authors' work described in this review was supported by the National Health and Medical Research Council of Australia and the Buckland Foundation. We thank Faye Coates for assistance in preparing the manuscript.

\section{References}

Ashworth, C.J. \& Bazer, F.W. (1989) Changes in ovine conceptus and endometrial function following asynchronous embryo transfer or administration of progesterone. Biol Reprod. 40, 425-434.

Basu, S. \& Kindahl, H. (1987) Prostaglandin biosynthesis and its regulation in the bovine endometrium: a comparison between pregnant and non-pregnant status. Theriogenology 28, 1755-1759.

Basu, S. \& Kindahl, H. (1989) Endogenous inhibition of arachidonic acid metabolism in the endometrium of the sheep. Prost. Leuk. \& Ess. Fatty Acids 35, 147-152.

Bazer, F.W. \& Thatcher, W.W. (1977) Theory of maternal recognition of pregnancy in swine based on estrogen controlled versus exocrine secretion of prostaglandin $\mathrm{F}_{2 a}$ by the uterine endometrium. Prostaglandins 14, 398-401.

Bazer, F.W., Vallet, J.L., Roberts, R.M., Sharp, D.C. \& Thatcher, W.W. (1986) Role of conceptus secretory products in establishment of pregnancy. $J$. Reprod. Fert. 76, 841-850.

Bazer, F.W., Vallet, J.L., Ashworth، C.J., Anthony, R.V. \& Roberts, R.M. (1987) The role of ovine conceptus secretory proteins in the establishment of pregnancy. Adv. exp. Med. Biol. 230, 22 I-235.

Cerini, J.C., Cerini, M., Findlay, J.K. \& Lawson, R.A.S. (1979) Localization of prostaglandin $F$ in the ovine uterus during early pregnancy. Anim. Reprod. Sci, 2, 363-372.

Charpigny, G., Reinaud, P., Huet, J-C., Guillomot, M., Charlier, M., Pernollet, J-C. \& Martal, J. (1988) High homology between a trophoblast protein (trophoblastin) isolated from ovine embryo and $\alpha$-interferons, FEBS letters, 288, 12-16.

Cherny, R.A. \& Findlay, J.K. (1988) Protein secretion patterns of separated ovine endometrial cells oultured in dual environment chambers. Proc Aust. Soc. Reprod. Biol. 19, 51, abstr.

Cherny, R.A. \& Findlay, J.K. (1990) Separation and culture of ovine endometrial and stromal cells: evidence of morphological and functional polarity. Biol. Reprod. 43 (in press).

Fincher, K.B., Bazer, F.W., Hansen, P.J., Thatcher, W.W. \& Roberts, R.M. (1986) Proteins secreted by the sheep conceptus suppress induction of uterine prostaglandin $\mathrm{F}-2 \alpha$ release by oestradiol and oxytocin. J. Reprod. Fert. 76, 425-433.

Findlay, J.K., Ackland, N., Burton, R.D., Davis, A.J., Maule Walker, F.M., Walters, D.E. \& Heap, R.B. (1981) Protein, prostaglandin and steroid synthesis in caruncular and intercaruncular endometrium of sheep before implantation. I. Reprod. Fert. 62, $361-377$.
Findlay, J.K., Clarke, I.J., Swaney, J., Colvin, N. \& Doughton, B. (1982) Oestrogen receptors and protein synthesis in caruncular and intercaruncular endometrium of sheep before implantation. J. Reprod. Fert. 64, 329-339.

Findlay, J.K., Cherny, R.A. \& Salamonsen, L.A. (1990a) Paracrine interactions amongst cells of the endometrium. In Contraception and Mechanisms of Endometrial Bleeding. Eds C. d'Arcangues, I. S. Frazer, J. R. Newton \& V. Olind. Cambridge University Press (in press).

Findlay, J.K., Salamonsen, L.A. \& Cherny, R.A. (1990b) The use of isolated cells to study endometrial function in vitro. Oxford Rev. Reprod. Biol. 12 (in press).

Flint, A.P.F., Leat, W.M.F., Sheldrick, E.L. \& Stewart, H.J. (1986) Stimulation of phosphoinositide hydrolysis by oxytocin and the mechanism by which oxytocin controls prostaglandin synthesis in the ovine endometrium. Biochem, $J_{+}$237, 797-805.

Fortier, M.A., Guilbault, L.A. \& Grasso, F. (1988) Specific properties of epithelial and stromal cells from the endometrium of cows. $J$. Reprod. Fert. 83, 239-248.

Godkin, J.D., Bazer, F.W., Moffatt, J., Sessions, F. \& Roberts, R.M. (1982) Purification and properties of a major low molecular weight protein released by the trophoblast of sheep blastocysts at Day 13-21.J. Reprod. Fert, 65, 141-50.

Godkin, J.D., Bazer, F.W. \& Roberts, R.M. (1984) Ovine trophoblast protein 1 , an early secreted blastocyst protein, binds specifically to uterine endometrium and affects protein synthesis. Endocrinology 114, 120-130.

Gross, T.S., Thatcher, W.W., Hansen, P.J. \& Lacroix, M.C. (1988a) Prostaglandin secretion by perifused bovine endometrium. Secretion towards the myometrial and luminal sides at day 17 post-estrus as altered by pregnancy. Prostaglandins 35, 327-340.

Gross, T.S., Thatcher, W.W., Hansen, P.J., Johnson, J.W. \& Helmer, S.D. (1988b) Presence of an intracellular endometrial inhibitor of prostaglandin synthesis during early pregnancy in the cow. Prostaglandins 35 , $359-378$.

Hansen, T.R., Imakawa, K., Polites, H.G., Marotti, K.R., Anthony, R.V. \& Roberts, R.M. (1988) Interferon RNA of embryonic origin is expressed transiently during early pregnancy in the ewe. J. biol. Chem. 263, 12801-12804.

Helmer, S.D., Gross, T.S., Newton, G.R., Hansen, P.J. \& Thatcher, W.W. (1989) Bovine trophoblast protein-1 complex alters endometrial protein and prostaglandin secretion and induces an intracellular inhibitor of 
prostaglandin synthesis in vitro. J. Reprod. Fert. 87, $421-430$.

Imakawa, K., Anthony, R.V., Kazemi, M., Marotti, K. R., Polites, H.G. \& Roberts, R.M. (1987) Interferon-like sequence of ovine trophoblast protein secreted by embryonic trophectoderm. Nature, Lond. 330, $377-379$,

Lacroix, M.C. \& Kann, C. (1983) Discriminating analysis of in witro prostaglandin release by myometrial and luminal sides of the ewe endometrium. Prostaglandins 25, 853-869.

McCracken, J.A., Schramm, W. \& Okulicz, W.C. (1984) Hormone receptor control of pulsatile secretion of $\mathrm{PGF}_{20}$ from the ovine uterus during luteolysis and its abrogation in early pregnancy. Anim. Reprod. Sci. 7, 31-55.

Peterson, A.J., Tervit, H.R., Fairclough, R.J., Havik, P.G. \& Smith, J.F. (1976) Jugular levels of 13,14dihydro-15-keto-prostaglandin $\mathrm{F}$ and progesterone around luteolysis and early pregnancy in the ewe. Prostaglandins 12, 551-558.

Philpott, S.D., Doughton, B., Salamonsen, L.A. \& Findlay, J.K. (1985) Oxytocin binding in sheep endometrium during the oestrous cycle and early pregnancy. Proc Aust. Soc Reprod. Biol. 17, 33, abstr.

Salamonsen, L.A. \& Findlay, J.K. (1990a) Regulation of endometrial prostaglandins during the menstrual cycle and in early pregnancy. Reprod. Fert. Dev. 2 (in press),

Salamonsen, L.A. \& Findlay, J.K. (1990b) Immunocytochemical localization of prostaglandin synthase in the ovine uterus during the oestrous cycle and in early pregnancy. Reprod. Fert. Dev. 2, 311-319.

Salamonsen, L.A., O, W.S., Doughton, B. \& Findlay, J.K. (1985) The effects of estrogen and progesterone in vivo on protein synthesis and secretion by cultured epithelial cells from sheep endometrium. Endocrinology 117, 2148-2159.

Salamonsen, L.A., Doughton, B.W. \& Findlay, J.K. (1986) The effects of the preimplantation blastocyst in vivo and in vitro on protein synthesis and secretion by cultured epithelial cells from sheep endometrium. Endocrinology 119, 622-628.
Salamonsen L.A., Stuchbery, S.J., O'Grady, C.M., Godkin, J.D. \& Findlay, J.K. (1988) Interferon $\alpha$ mimics effects of ovine trophoblast protein-1 on prostaglandin and protein secretion by ovine endometrial cells in vitro. J. Endocr, 117, R1-R4.

Salamonsen, L.A., Manikhot, J., Healy, D.L. \& Findlay, J.K. (1989) Ovine trophoblast protein-1 and human interferon $\alpha$ reduce prostaglandin synthesis by ovine endometrial cells. Prostaglandins 38, 289-306.

Sharif, S.F., Francis, H., Keisler, D.H. \& Roberts, R.M. (1989) Correlation between the release of ovine trophoblast protein-] by the conceptus and the production of polypeptides by the maternal endometrium of ewes. J. Reprod. Fert. 85, 471-476.

Stewart, H.J., McCann, S.H.E., Barker, P.J., Lee, K.E., Lamming, G.E. \& Flint, A.P.F. (1987) Interferon sequence homology and receptor binding activity of ovine trophoblast antiluteolytic protein. $J$. Endocr. 115, R13-R15.

Stewart, H.J., Flint, A.P.F., Lamming, G.E., McCann, S.H.E. \& Parkinson, T.J. (I989) Antiluteolytic effects of blastocyst-secreted interferon investigated in vitro and in vivo in the sheep. J. Reprod. Fert., Suppl. 37, 127-138.

Vallet, J.L., Bazer, F.W. \& Roberts, R.M. (1987) The effect of ovine trophoblast protein-one on endometrial protein secretion and cyclic nucleotides. Biol. Reprod. 37, 1307-1316.

Vallet, J.L., Bazer, F.W., Fliss, M.F.V. \& Thatcher, W.W. (1988) Effect of ovine conceptus secretory proteins and purified ovine trophoblast protein-1 on interoestrous interval and plasma concentrations of prostaglandins $\mathrm{F}-2 \alpha$ and $\mathrm{E}$ and of 13,14-dihydro-I5keto prostaglandin $\mathrm{F}-2 \alpha$ in cyclic ewes. $J$. Reprod. Fert. 84, 493-504.

Vallet, J.L., Gross, T.S., Fliss, M.F.V. \& Bazer, F.W. (1989) Effects of pregnancy, oxytocin, ovine trophoblast protein- $I$ and their interactions on endometrial production of prostaglandin $\mathrm{F}_{20}$ in vitro in perifusion chambers. Prostaglandins 38, 113-124.

Weck, P.K., Apperson, S., May, L. \& Stebbing, N. (1981) Comparison of the antiviral activities of various cloned human interferon- $\alpha$ subtypes in mammalian cell cultures. J. gen. Virol. 57, 233-237. 